\title{
High Flux Isotope Reactor Quarterly Report July, August, and September of 1977
}
B. L. Corbett
R. V. McCord
K. H. Poteet

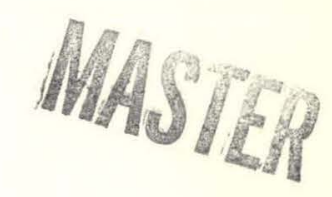




\section{DISCLAIMER}

This report was prepared as an account of work sponsored by an agency of the United States Government. Neither the United States Government nor any agency Thereof, nor any of their employees, makes any warranty, express or implied, or assumes any legal liability or responsibility for the accuracy, completeness, or usefulness of any information, apparatus, product, or process disclosed, or represents that its use would not infringe privately owned rights. Reference herein to any specific commercial product, process, or service by trade name, trademark, manufacturer, or otherwise does not necessarily constitute or imply its endorsement, recommendation, or favoring by the United States Government or any agency thereof. The views and opinions of authors expressed herein do not necessarily state or reflect those of the United States Government or any agency thereof. 


\section{DISCLAIMER}

Portions of this document may be illegible in electronic image products. Images are produced from the best available original document. 
Printed in the United States of America. Available from National Technical Information Service

U.S. Department of Commerce 5285 Port Royal Road, Springfield, Virginia 22161

Price: Printed Copy $\$ 4.00$; Microfiche $\$ 3.00$

This report was prepared as an account of work sponsored by an agency of the United States Government. Neither the United States Government nor any agency thereof, nor any of their employees, contractors, subcontractors, or their employees, makes any warranty, express or implied, nor assumes any legal liability or responsibility for any third party's use or the results of such use of any information, apparatus, product or process disclosed in this report, nor represents that its use by such third party would not infringe privately owned rights. 
ORNL/TM- 6188

Contract No. W-7405-eng-26

Operations Division

HIGH FLUX ISOTOPE REACTOR QUARTERLY REPORT

JULY, AUGUST, AND SEPTEMBER OF 1977

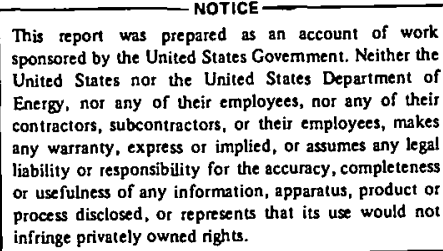

infringe privately owned rights.
B. L. Corbett
R. V. McCord
K. H. Poteet

Date Published - December 1977

NOTICE This document contains information of a preliminary nature.

It is subject to revision or correction and therefore does not represent a final report.

\author{
OAK RIDGE NATIONAL LABORATORY \\ Oak Ridge, Tennessee 37830 \\ operated by \\ UNION CARBIDE CORPORATION \\ for the \\ DEPARTMENT OF ENERGY
}




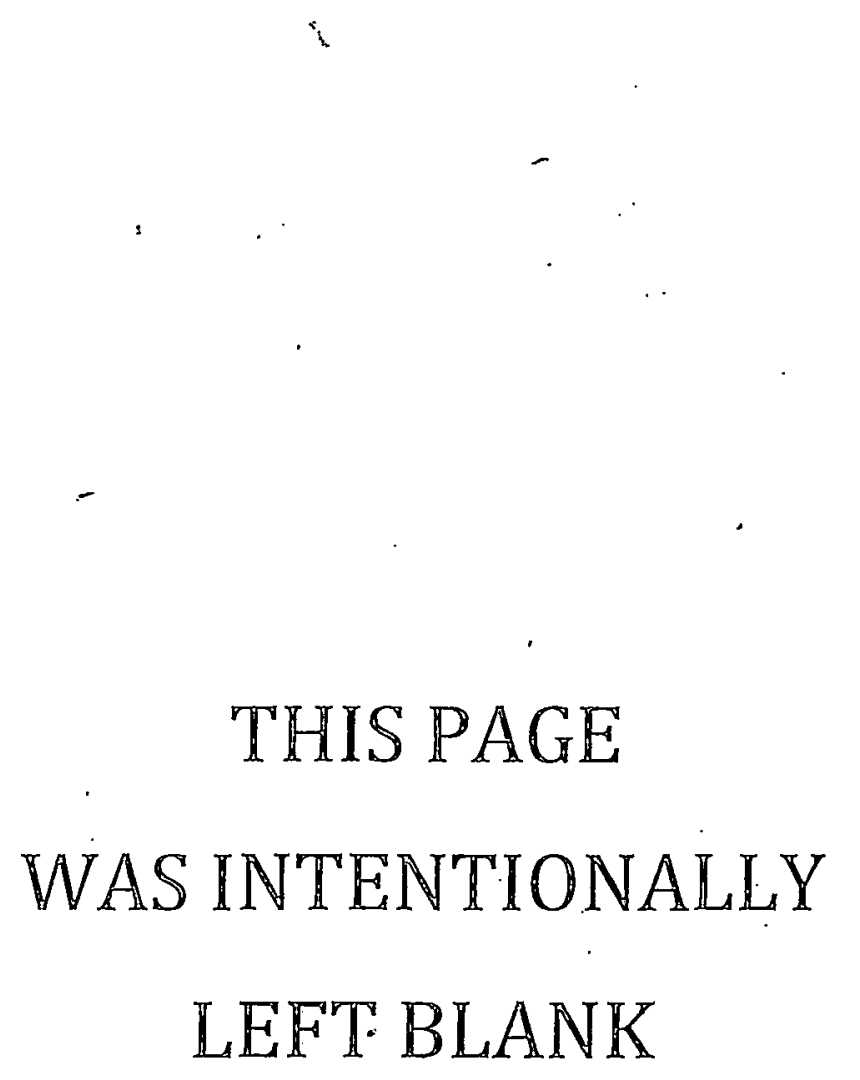




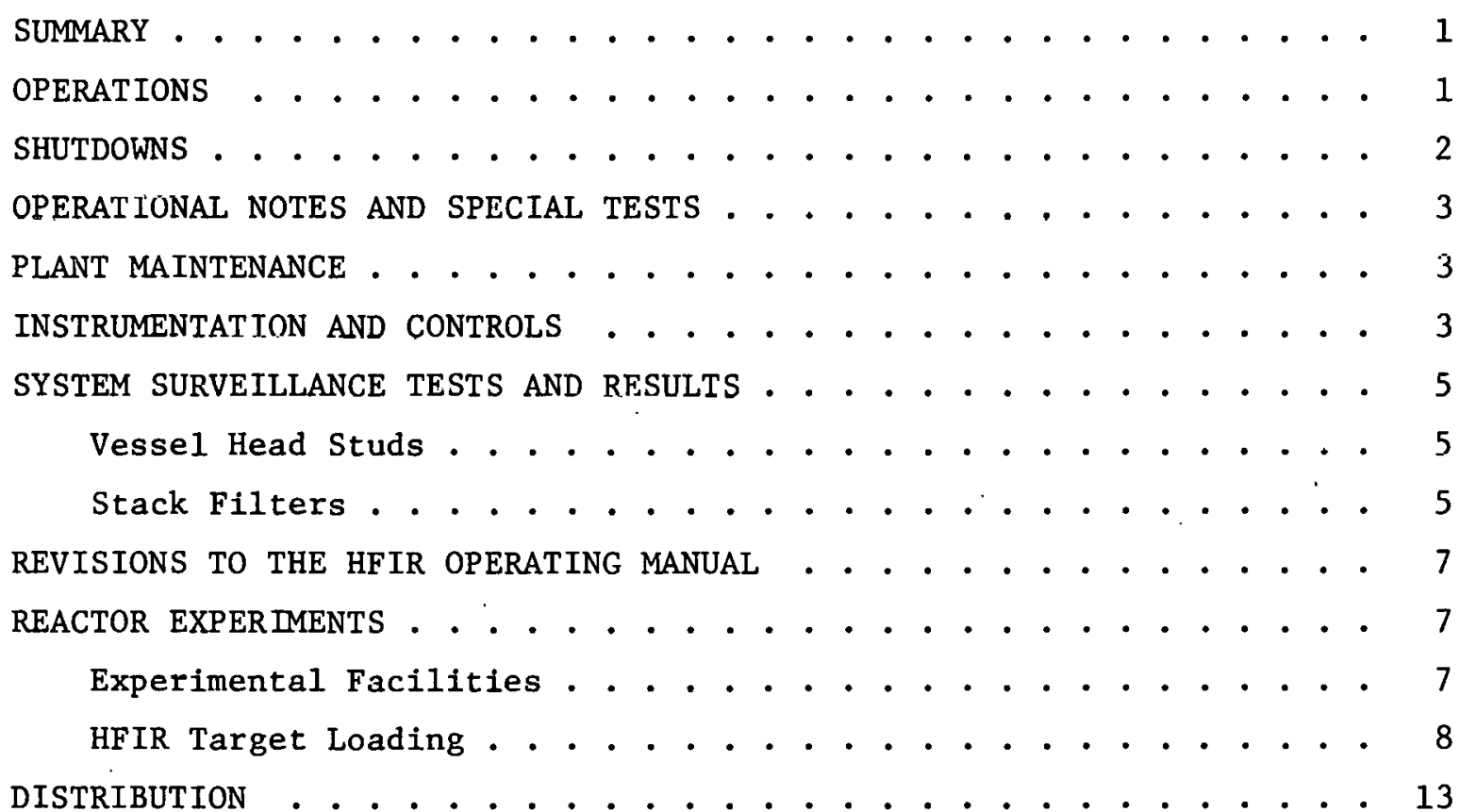




\section{SUMMARY}

Routine reactor operation with three end-of-cycle shutdowns and the completion of a fourth carried over from last quarter resulted in an onstream time of $95.5 \%$. The control plates were changed, and a new inner control cylinder was installed.

\section{OPERATIONS}

Basic operating data for the quarter are listed in Table 1.

Table 1. HFIR Basic Operating Data

(July 1, 1977 through September 30, 1977).

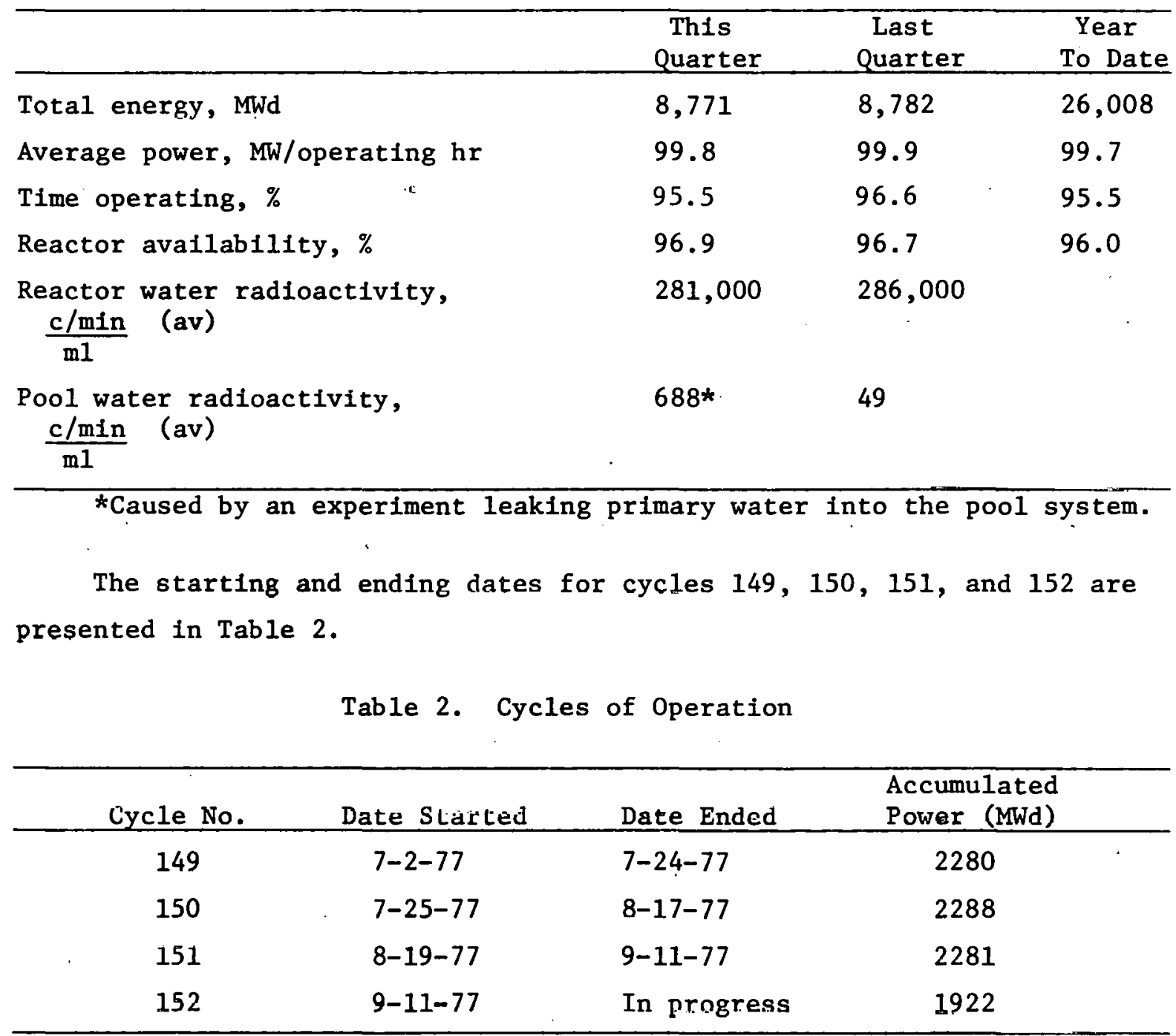


The status of the HFIR fuel and control-plate inventory is indicated in Table 3.

Table 3. HFIR Material Inventory

\begin{tabular}{lcc}
\hline \multicolumn{1}{c}{ Item } & This & Last \\
\hline Quarter & Quarter \\
New fuel elements placed in service & 4 & 3 \\
Spent fuel elements on hand & 47 & 45 \\
Spent tuel elements shipped & 10 & 15 \\
New sets of shim plates placed in service & 8 & 2 \\
New sets of shim plates available for use & 0 & 0 \\
\hline
\end{tabular}

\section{SHUTDOWNS}

There were four end-of-cycle shutdowns, one of which was continued from last quarter, and one reactor control demonstration shutdown for a total downtime of 98.850 hours. There were no unscheduled shutdowns this quarter. Table 4 gives further details of the shutdowns.

Table 4. Description of HFIR Shutdowns

\begin{tabular}{|c|c|c|}
\hline Date & $\begin{array}{l}\text { Downtime } \\
(h r)\end{array}$ & Remarks \\
\hline $7-1-77$ & 25.617 & $\begin{array}{l}\text { This downtime was a continuation from last quarter of } \\
\text { the end of fuel cycle } 148 \text { shutdown. }\end{array}$ \\
\hline $7-24-77$ & 21.300 & $\begin{array}{l}\text { Fuel cycle } 149 \text { was completed at } 9: 30 \mathrm{p} . \mathrm{m} \text {. A total power } \\
\text { generation of } 2280 \text { MWd was obtained on fuel elements } \\
145-0 \text { and } 145-1 \text {. }\end{array}$ \\
\hline $8-17-77$ & 36.083 & $\begin{array}{l}\text { Fuel cycle } 150 \text { was completed at } 4: 00 \mathrm{p} . \mathrm{m} \text {. A total power } \\
\text { generation of } 2288 \mathrm{MWd} \text { was obtained on fuel elements } \\
148-0 \text { and } 148-1 \text {. }\end{array}$ \\
\hline $9-11-77$ & 15.733 & $\begin{array}{l}\text { Fuel cycle } 151 \text { was completed at } 2: 27 \text { a.m. A total power } \\
\text { generacion of } 2281 \text { MWd was obtained on fuel elements } \\
149-0 \text { and } 149-1 \text {. }\end{array}$ \\
\hline $9-14-77$ & 0.117 & $\begin{array}{l}\text { At the request of the Instrumentation and Controls } \\
\text { Division, the reactor was shut down to demonstrate the } \\
\text { performance of the HFIR control and safety systems. }\end{array}$ \\
\hline
\end{tabular}


OPERATIONAL NOTES AND SPECIAL TESTS

To comply with the survelllance requirements of the HFIR technical specifications, a number of special tests were completed this quarter. The nominal speed of the shim rod drives is $6 \mathrm{in.} / \mathrm{min}$. Measuring this parameter for each shim rod gave the following results:

\begin{tabular}{cc} 
Shim Rod No. & Drive Speed, in./min. \\
\hline 1 & 5.91 \\
2 & 5.98 \\
3 & 5.84 \\
4 & 6.00 \\
5 & 6.05
\end{tabular}

The servo controlled portion of the shim rod stroke is limited to a nominal $15 \mathrm{in./min.} \mathrm{over} \mathrm{a} \mathrm{1-in.} \mathrm{span.} \mathrm{When} \mathrm{this} \mathrm{movement} \mathrm{was} \mathrm{measured} \mathrm{on}$ a high speed recorder, the servo control was found to have a speed of $14.4 \mathrm{in./min}$. over an 0.815 -in. span.

A "Case IV" shutdown margin measurement was also made. The Case IV conditions are the most severe combination of two independent control system failures considered in the HFIR safety analysis report. It consists of a fallure of one safety rod to scram and a runaway of one safety rod (the same rod). The limiting condition is that the reactor be subcritical with the runaway rod at its withdraw limit, the control cylinder at the original symmetric critical position, and the remaining three safety rods completely inserted. The measurement showed that the reactor was subcritical with one safety rod at its withdraw limit, the control cylinder at its symmetric critical position, and the three remaining safety rods withdrawn less than 16.40 in.

\section{PLANT MAINTENANCE}

Maintenance and changes in the various process systems are listed in Table 5 .

\section{INSTRUMENTATION AND CONTROLS}

Maintenance and changes in the various instrumentation systems are listed in Table 6 . 
Table 5. Process Systems - Maintenance and Changes

\begin{tabular}{lll}
\hline Date & Component & Remarks \\
\hline $8-15-77$ & Demineralizer resin & $\begin{array}{c}\text { Primary System } \\
\text { The cation resin in the west primary demineralizer was replaced } \\
\text { because of radiation damage. }\end{array}$ \\
$9-17-77$ & Heat exchanger & $\begin{array}{c}\text { A leaking tube in heat exchanger EX-1A was plugged. Two other tubes } \\
\text { in locations most likely to develop leaks were plugged. }\end{array}$ \\
$8-8-77$. & Prefilters & $\begin{array}{c}\text { Miscellaneous } \\
\text { The fiberglas prefilters in the SBHE center filter pit were replaced } \\
\text { because of excessive pressure drop. } \\
\text { The electrical breaker for cooling tower fan } 4 \mathrm{D}-2 \text { caught fire and } \\
\text { burned out forcing a power reduction to } 90 \text { MW unt11 it could be } \\
\text { replaced. }\end{array}$ \\
\hline
\end{tabular}


Table 6. Instrumentation - Maintenance and Changes

\begin{tabular}{lll}
\hline Date & Component & Remarks \\
\hline $8-22-77$ & Servo motor & $\begin{array}{l}\text { The No. } 1 \text { servo motor was replaced because of a } \\
\text { nolsy bearing. }\end{array}$ \\
9-20-77 & HV supply & $\begin{array}{l}\text { The amplifier in the No. } 1 \text { channel Failed Fuel } \\
\text { Element Detector was replaced because of a low } \\
\text { output voltage on the HV supply. This was } \\
\text { detected during a routine safety channel check } \\
\text { procedure by I\&C personnel. }\end{array}$ \\
\hline
\end{tabular}

SYSTEM SURVEILLANCE TESTS AND RESULTS

Vessel Head Studs

The accumulated number of tensioning cycles on the reactor vessel head studs is presented in Table 7. These studs were designed for a fatigue life of 40 cycles loading due to tensioning of the bolts and 730 full-pressure (1000 psig) cycles. Installation of new reactor vessel head studs was completed in June, 1972. The numbers in Table 8 represent the maximum cycles to which any new stud has been exposed.

Table 7. Vessel Head Stud-Tensioning Cycles

\begin{tabular}{lccc}
\hline \multicolumn{1}{c}{ Type Cycle } & $\begin{array}{c}\text { This } \\
\text { Quarter }\end{array}$ & $\begin{array}{c}\text { Last } \\
\text { Quarter }\end{array}$ & $\begin{array}{c}\text { Total } \\
\text { To Date }\end{array}$ \\
\hline Head bolts tensioned & 0 & 0 & 6 \\
1500 psig & & & 0 \\
950 psig & 0 & 0 & 7 \\
750 psig & 5 & 3 & 10 \\
650 psig & 0 & 3 & 117 \\
\hline
\end{tabular}

\section{Stack Filters}

Stack filtering systems in the special building hot exhaust (SBHE) and hot off-gas (HOG) systems were tested for iodine removal efficiency. Results of the most recent tests are tabulated in Table 8 . 
Table 8. Particulate and Iodine Removal Efficiency

\begin{tabular}{|c|c|c|c|c|c|c|c|c|c|c|c|c|c|}
\hline \multirow[b]{3}{*}{ Filter Bank } & \multicolumn{4}{|c|}{ Methyl Iod1de } & \multicolumn{4}{|c|}{ Elemental Iodine } & \multirow{3}{*}{$\begin{array}{c}\text { Filter } \\
\text { Position }\end{array}$} & \multicolumn{4}{|c|}{ Particulate Retention } \\
\hline & \multicolumn{2}{|c|}{ Last Test } & \multicolumn{2}{|c|}{ Previous Test } & \multicolumn{2}{|c|}{ Last Test } & \multicolumn{2}{|c|}{ Previous Test } & & \multicolumn{2}{|c|}{ Last Test } & \multicolumn{2}{|c|}{ Previous Test } \\
\hline & Date & Eff., \% & Dace & EEf.. $\%$ & Date & Eff., \% & Date & Eff., \% & & Date & Eff., \% & Date & Eff., 7 \\
\hline \multirow[t]{2}{*}{ SBHE, west } & $3-29-77$ & 44 & $11-9-76$ & 82.84 & $3-8-77$ & 99.9 .3 & $10-8-76$ & 99.94 & South & $3-28-77$ & 99.997 & $3-21-77$ & 99.995 \\
\hline & & . & & & & & & & North & $3-28-77$ & 99.995 & $3-21-77$ & 99.996 \\
\hline \multirow[t]{2}{*}{ SBHE, center } & $5-3-77$ & 80 & $11-17-7 \epsilon$ & 87 & $3-23-77$ & 99.94 & $10-21-76$ & $99.9 \varepsilon$ & South & $3-28-77$ & 99.997 . & $3-21-77$ & 99.994 \\
\hline & & & & & & & & & North & $7-28-77$ & 99.953 & $3-30-77$ & 99.996 \\
\hline \multirow[t]{2}{*}{ SBHE, east } & $4-21-77$ & 64 & $11-12-7 \epsilon$ & $\angle 8$ & $3-18-77$ & 99.94 & $10-14-76$ & 99.93 & South & $3-28-77$ & 99.982 & $3-30-77$ & 99.995 \\
\hline & . & - & & & & & & & North & $3-28-77$ & 99.994 & $3-21-77$ & 99.990 \\
\hline HOG, west & $5-19-77$ & 98 & $11-16-7 \epsilon$ & 59 & $3-16-77$ & 99.99 & $10-26-76$ & 99.99 & & & & & \\
\hline HOG, center & $5-17-77$ & 60 & $11-18-7 \epsilon$ & 98 & $4-1-77$ & $39.9:$ & $11-4-76$ & 99.99 & & & & & \\
\hline HOG, east & $5-20-77$ & 88 & $11-10-7 \epsilon$ & 92 & $3-8-77$ & 99.93 & $10-12-76$ & 99.96 & & & & & \\
\hline
\end{tabular}


REVISIONS TO THE HFIR OPERATING MANUAL

Revisions and additions to the HFIR operating manual which have been published this quarter are tabulated in Table 9.

Table 9. HFIR Manual Revisions

\begin{tabular}{cccc}
\hline Date & $\begin{array}{c}\text { Section } \\
\text { No. }\end{array}$ & Subject & General Description \\
\hline 8-25-77 & II-13 & $\begin{array}{c}\text { Technical specifica- } \\
\text { tions requirements }\end{array}$ & $\begin{array}{l}\text { A complete chapter addition } \\
\text { covering surveillance require- } \\
\text { ments of the HFIR technical } \\
\text { specifications. }\end{array}$ \\
& & &
\end{tabular}

REACTOR EXPERIMENTS

Experimental Facilities

Usage of the various HFIR experiment facilities is tabulated in Table 10.

Table 10. Experiment Facility Usage

\begin{tabular}{|c|c|c|}
\hline Fac1l1ty & Description & Division \\
\hline PTP-Al & Materials studies & Metals and Ceramics \\
\hline PTP-A4 & Materials studies & Metals and Ceramics \\
\hline PTP-D1 & Materials studies & Metals and Ceramics \\
\hline PTP-D7 & Materials studies & Metals and Ceramics \\
\hline PTP-G4 & Materials studies & Metals and Ceramics \\
\hline PTP-G7 & Materials studies & Metals and Ceramics \\
\hline $\mathrm{RB}-1$ & Isotope production & Operations \\
\hline $\mathrm{RB}-2$ & Isotope production & Operations \\
\hline $\mathrm{RB}-3$ & Isotope production & Operations \\
\hline $\mathrm{RB}-4$ & HFIR tensile specimens & Operations \\
\hline $\mathrm{RB}-5$ & HTGR fuel irradiations & Engineering Technology \\
\hline $\mathrm{RB}-6$ & Isotope production & Operations \\
\hline $\mathrm{RB}-7$ & HTGR fuel irradiations & Englneering Technology \\
\hline $\mathrm{RB}-8$ & Isotope production & Operations \\
\hline
\end{tabular}


Table 10. (continued)

\begin{tabular}{lll}
\hline Facility & \multicolumn{1}{c}{ Description } & \multicolumn{1}{c}{ Division } \\
\hline CR-1 & Isotope production & Operations \\
CR-2 & Isotope production & Operations \\
CR-3 & Californium production & Chemical Technology \\
CR-4 & Californium production & Chemical Technology \\
CR-5 & Isotope production & Operations \\
CR-6 & Isotope production & Operations \\
CR-7 & Isotope production & Operations \\
CR-8 & Isotope production & Operations \\
VXF-1 & HFIR corrosion specimen & Operations \\
VXF-7 & Pneumatic tube & Analytical Chemistry \\
VXF-13 & HTGR fuel irradiations & Engineering Technology \\
EF-2 & Noise analysis studies & Instrumentation and Controls \\
& & and Operations \\
HB-1 & Neutron diffractometer & Solid State \\
HB-2 & Neutron diffractometer & Chemistry \\
HB-3 & Neutron diffractometer & Solid State \\
HB-4 & Neutron diffractometer & Solid State \\
\hline
\end{tabular}

HFIR Target Loading

A description of the HFIR target loading for each of the operating cycles this quarter is presented in Figures $1,2,3$, and 4. 


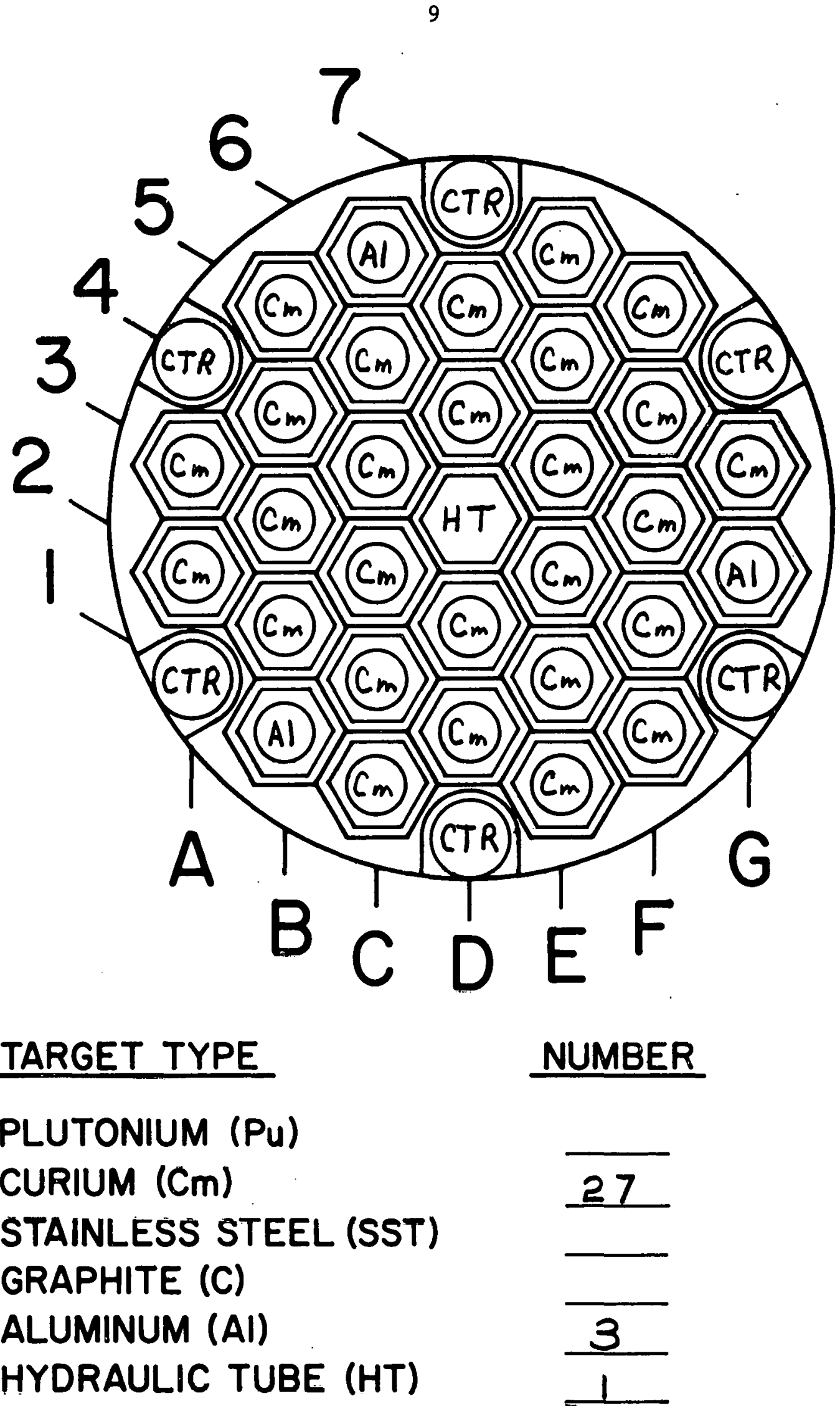

Fig. 1. HFIR Target Loading for Cycle 149 - July 2, 1977 


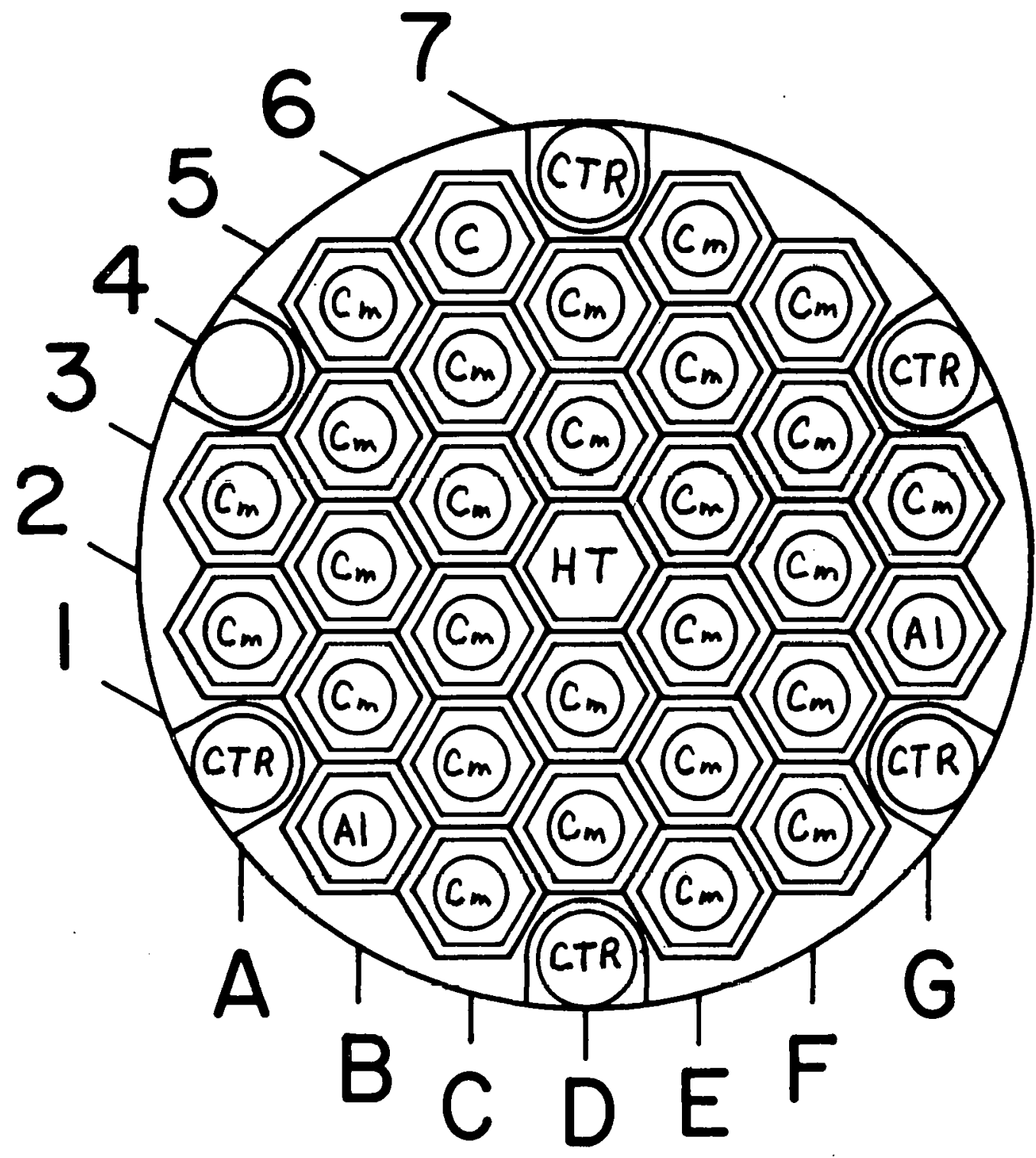

TARGET TYPE

NUMBER

PLUTONIUM (Pu)

CURIUM $(\mathrm{Cm})$.

STAINLESS STEEL (SST)

GRAPHITE (C)

ALUMINUM (AI)

HYDRAULIC TUBE (HT)
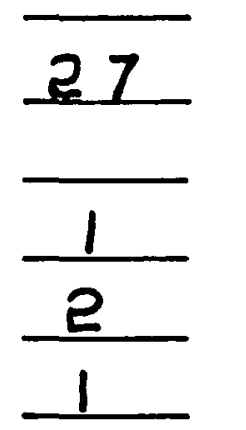

Fig. 2. HFIR Target Loading for Cycle 150 - July 25, 1977 


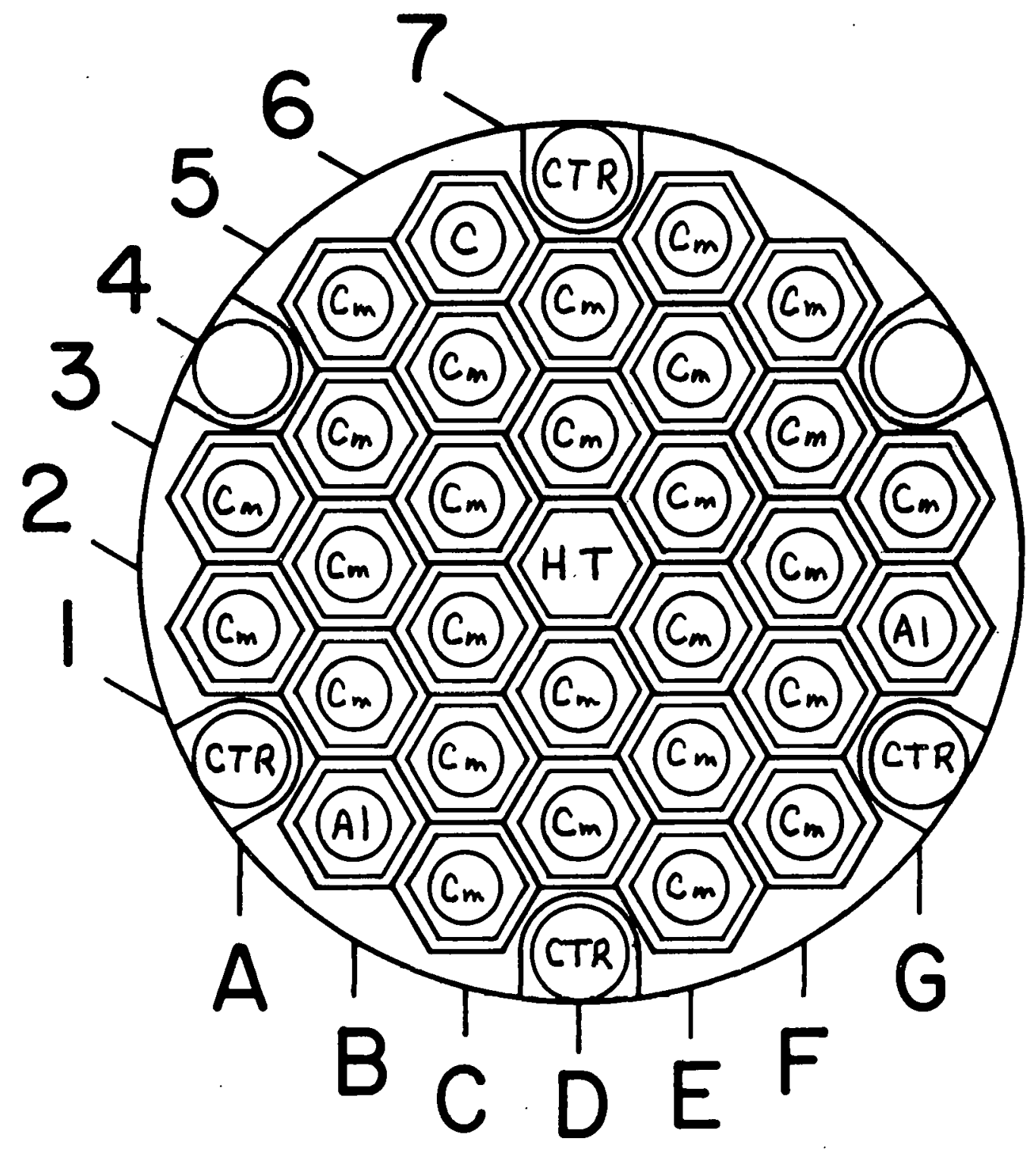

TARGET TYPE

NUMBER

PLUTONIUM (Pu)

CURIUM $(\mathrm{Cm})$

STAINLESS STEEL (SST)

GRAPHITE (C)

ALUMINUM (AI)

HYDRAULIC TUBE (HT)

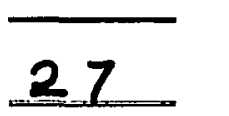

Fig. 3. HFIR Target Loading for Cycle 151 - August 19, 1977 


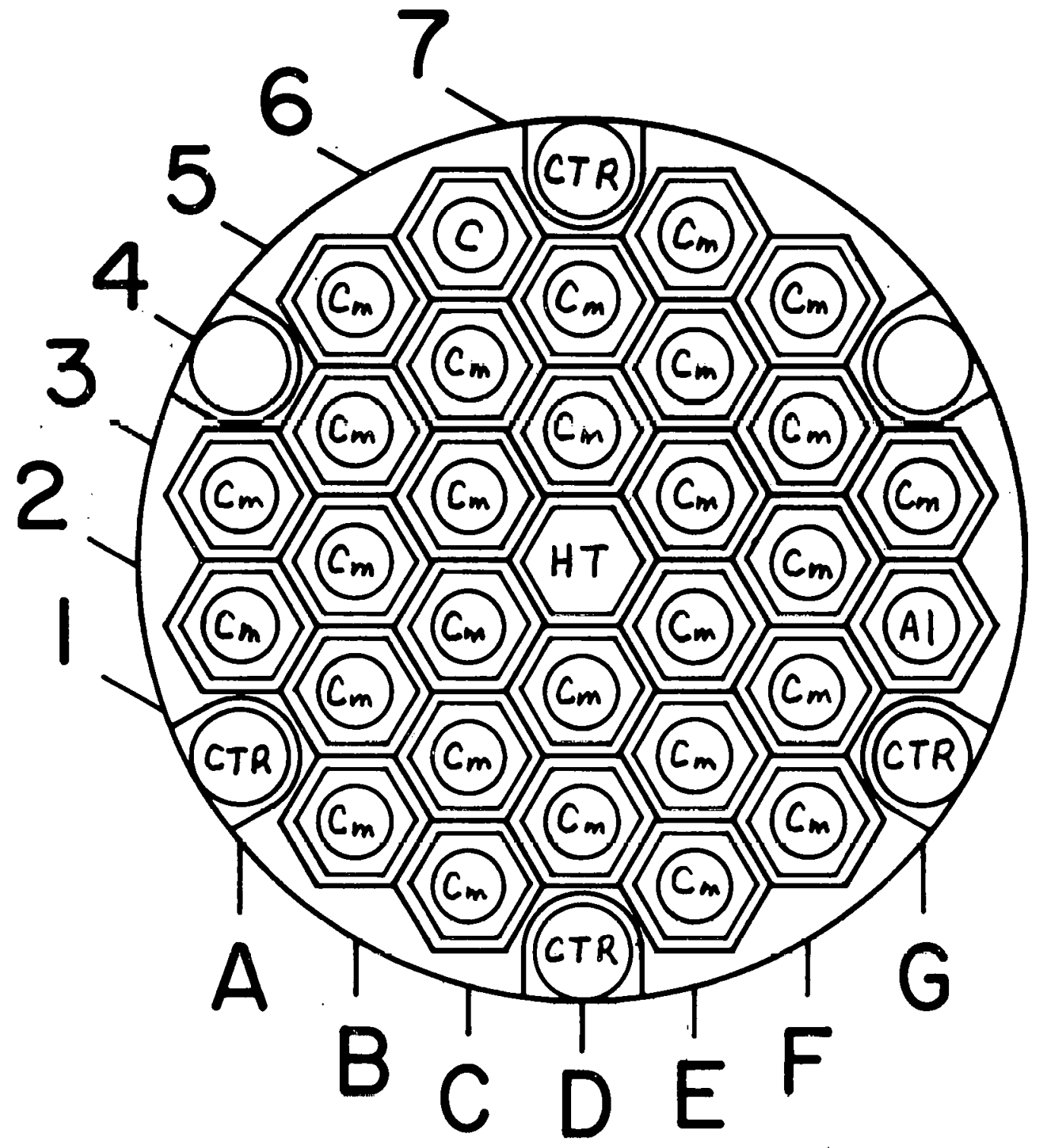

TARGET TYPE

NUMBER

PLUTONIUM (PU)

CURIUM (Cm)

STAINLESS STEEL (SST)

GRAPHITE (C)

ALUMINUM (AI)

HYDRAULIC TUBE (HT)
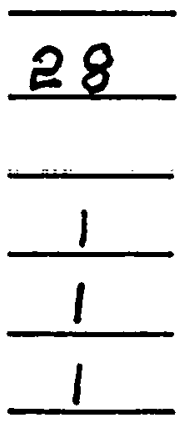

Fig. 4. HFIR Target Loading for Cycle 152 - September 11, 1977 
INTERNAL DISTRIBUTION

ORNL/TM-6188

1. G. M. Adamson

2. J. L. Anderson

3. D. S. Asquith

4. K. S. Belitz

5. J. E. Bigelow

6. D. S. Billington

7. F. T. Binford

8. G. H. Burger

9. C. D. Cagle

10. W. R. Casto

11. R. D. Cheverton

12. T. E. Cole

13. J. A. Conlin

14-16. B. L. Corbett

17. J. A. Cox

18. W. H. Culbert

19. S. J. Ditto

20. G. J. Dixon

21. K. Farrell

22. R. H. Guymon

23. T. P. Hamrick

24. C. H. Helton

25. S. S. Hurt, III

26. G. H. Jenks

27. E. B. Johnson

28. S. I. Kaplan

29. O. L. Keller

30. E. M. King

31. H. V. Klaus

32. R. W. Knight
33. W. C. Koehler

34. E. Lamb

35. H. A. Levy

36. J. Lewin

37-42. R. V. McCord

43. J. R. McGuffey

44. H. A. McLain

45. J. R. McWherter

46. J. M. Miller

47. L. C. Oakes

48. H. Postma

49. K. H. Poteet

50. M. E. Ramsey

51. R. L. Scott, Jr.

52. W. H. Sides

53. T. M. Sims

54. M. J. Skinner

55. J. H. Swanks

56. J. R. Thomas

57. D. B. Trauger

58. J. R. Weir

59. K. W. West

60. F. W. Wiffen

61. M. K. Wilkinson

62. J. W. Woods

63. A. Zucker

64-65. Central Research Library

66. Document Reference Section

67-68. Laboratory Records Department

69. Laboratory Records, ORNL R.C.

\section{EXTERNAL DISTRIBUTION}

70-96. Technical Information Center, Oak Ridge

97-98. M. B. Biles, Director, Division of Safety, Standards, and Compliance, DOE, Washington, D. C. 20545

99. K. J. Bobin, Centre D'Etude de Energie Nucleaire, S.C.K./C.E.N, Boeretang 200, B-2400 Mo1, Belgium

100. J. L. Burnett, Division of Physical Research, DOE, Washington, D. C. 20545

101. H. N. Culver, DOE, Oak Ridge

102. M. Jacquemain, Head, Technical Department ILL, Institute Max von Laue-Paul Langevin, CEDEX 156, 38 Grenoble-Gare, France

103. G. L. Rogosa, Division of Physical Research, DOE, Washington, D. C. 20545

104. Research and Technical Support Division, DOE, Oak Ridge

105. A. C. Wood, Australian AEC, Nuclear Science and Technology Branch, Private Mail Bag, Sutherland 2232, New South Wales, Australia 